\section{High prevalence of vitamin D deficiency among newly diagnosed youth-onset diabetes mellitus in north India}

\author{
Alta prevalência de deficiência de vitamina $D$ entre casos de diabetes \\ de início na juventude recém-diagnosticada no norte da Índia
}

Riyaz Ahmad Daga', Bashir Ahmad Laway', Zaffar Amin Shah², Shahnaz Ahmad Mir', Suman Kumar Kotwal', Abdul Hamid Zargar ${ }^{1}$

\begin{abstract}
Objectives: Vitamin D deficiency is common at all ages, and low levels of vitamin D have been associated with high incidence of type 1 diabetes. Similar results are not consistent for type 2 diabetes. The aim of the present study was to estimate vitamin D status in newly detected youth-onset diabetes in north India. Subjects and methods: This was a prospective case control study at a tertiary care hospital in north India. Seventy two newly detected youth-onset diabetes subjects (age $<25$ years), and 41 age- and gender-matched healthy controls were studied. In addition to basic information and management regarding their diabetes, metabolic parameters and serum $25(\mathrm{OH}) \mathrm{D}$ were measured in both the groups. Results: Vitamin D deficiency was seen in $91.1 \%$ of the subjects with diabetes, and $58.5 \%$ of the healthy controls. Mean \pm SD $25(\mathrm{OH}) \mathrm{D}$ was significantly low, $7.88 \pm 1.20 \mathrm{ng} / \mathrm{mL}$ in subjects with diabetes against $16.64 \pm 7.83 \mathrm{ng} / \mathrm{mL}$ in controls. Sixty percent of cases had severe Vitamin D deficiency compared with $8.3 \%$ in controls. Levels of vitamin D did not correlate with clinical parameters, such as gender, body mass index; or with biochemical parameters, such as serum calcium, phosphorus, alkaline phosphatase, fasting plasma glucose, and $\mathrm{HbA} 1 \mathrm{C}$. Conclusion: Vitamin D deficiency is common in people with youth-onset diabetes. Arq Bras Endocrinol Metab. 2012;56(7):423-8
\end{abstract}

\section{Keywords}

Vitamin D deficiency; youth-onset diabetes; type 2 diabetes; 25(OH)D

\section{RESUMO}

Objetivos: A deficiência de vitamina D é comum em todas as idades, e baixas concentrações de vitamina $\mathrm{D}$ estão associadas à alta incidência de diabetes tipo 1. Entretanto, resultados similares não são consistentes para o diabetes tipo 2. 0 objetivo do presente estudo foi estimar a condição dos pacientes com relação à vitamina $D$ em casos de diabetes de início na juventude recém-diagnosticada no norte da Índia. Sujeitos e métodos: Este foi um estudo prospectivo controlado em um hospital de cuidados terciários no norte da Índia. Setenta e dois pacientes com diabetes de início na juventude recém-diagnosticada (idade $<25$ anos) e 41 controles saudáveis, sem diabetes, pareados por idade e sexo, foram estudados. Além das informações básicas e controle do diabetes, parâmetros metabólicos e a 25(OH)D sérica foram avaliados em ambos os grupos. Resultados: A deficiência de vitamina D foi observada em $91,1 \%$ dos pacientes com diabetes e em $58,5 \%$ dos controles saudáveis. A média \pm DP de $25(\mathrm{OH}) \mathrm{D}$ foi significativamente baixa, 7,88 $\pm 1,20 \mathrm{ng} / \mathrm{mL}$ nos pacientes com diabetes contra $16,64 \pm 7,83 \mathrm{ng} / \mathrm{mL}$ nos controles. Sessenta por cento dos pacientes com diabetes apresentaram deficiência grave de vitamina $D$, contra 8,3\% dos controles. As concentrações de vitamina $\mathrm{D}$ se correlacionaram com os parâmetros clínicos, como sexo, índice de massa corporal, ou com parâmetros bioquímicos, como cálcio e fósforo séricos, fosfatase alcalina, glicemia de jejum e $\mathrm{HbA1C}$. Conclusão: A deficiência de vitamina $D$ é comum em pacientes com diabetes de início na juventude. Arq Bras Endocrinol Metab. 2012;56(7):423-8

Descritores

Deficiência de vitamina D; diabetes de início na juventude; diabetes tipo 2; 25(OH)D
Department of Endocrinology, Sher-l-Kashmir Institute of Medical Sciences, Srinagar, India 2 Department of Immunology, Sher-I-Kashmir Institute of Medical Sciences, Srinagar, India

Correspondence to: Bashir Ahmad Laway drlaway@gmail.com

Received on July/4/2012 Accepted on Aug/13/2012 


\section{INTRODUCTION}

$\mathrm{V}$ itamin D deficiency (VDD) is presently a major health problem in both adults and children across the globe, and it is more so in the Indian subcontinent (1-4). Many studies that focused on pediatric age have demonstrated high prevalence of VDD in normal children and adolescents $(5,6)$. In the past decade, interest in diabetes mellitus and vitamin $\mathrm{D}$ metabolism has grown. Many epidemiological studies have found high prevalence of VDD in children with type 1 diabetes mellitus (TIDM), suggesting an association between the two (7-10). Type $1 \mathrm{DM}$ is an autoimmune disease with contribution from environmental insults in its causation (11). In susceptible persons, cytokine production and lymphocyte proliferation has been postulated to be decreased by immunomodulatory actions of vitamin $\mathrm{D}$, thus preventing destruction of beta-cells and subsequent development of TIDM (12). These observations are supported by many clinical studies where it has been shown that supplementation of vitamin D during early childhood helps preventing TIDM (13). There have also been many suggestions about the association of VDD and the incidence of type 2 diabetes mellitus (T2DM). Studies have suggested an inverse relationship between low intake of total vitamin $\mathrm{D}$ and risk of T2DM $(14,15)$. Similarly, supplementation of vitamin $\mathrm{D}$ in high risk groups, such as in patients with impaired fasting blood glucose levels, resulted in decreased rise in fasting plasma glucose and insulin resistance after three years, compared with the placebo group (16).

Kashmir valley is situated at an altitude of 1,574-5,425 feet above the sea level at latitudes $32020^{\circ}-34050^{\circ} \mathrm{N}$ and longitude $73045^{\circ}-75035^{\circ} \mathrm{E}$, in the Northern mountainous regions of India, with cold temperatures during six months of the year. However, the exposure to sunlight and consumption of dairy products are acceptable. The area has a high prevalence of diabetes across different age groups $(17,18)$. The prevalence of VDD is quite common in the adult population (19). The aim of the present study was to assess vitamin $\mathrm{D}$ status in the young population with diabetes and age- and gender-matched controls.

\section{SUBJECTS AND METHODS}

The present prospective case control study was conducted at a tertiary care hospital in north India over a period of two years. This study included 72 cases of youth-onset diabetes mellitus (age of onset of diabetes
$<25$ years), and 41 age- and sex-matched healthy control subjects. Cases with new onset diabetes aged below twenty five years of age were recruited and classified during the two years of observation. Subjects were classified as TIDM, if they had an episode of ketoacidosis; as T2DM if they had no episode of ketoacidosis and were controlled on oral antidiabetic drugs for more than a year after diagnosis; and as fibrocalculous pancreatopathy (FCPP) if they had pancreatic calcification on abdominal X-ray in addition to diabetes (17). Age-, sex- and body mass index-matched healthy subjectsbelow 25 years of age were identified and included as controls. Informed consent was obtained from all the subjects and controls after explaining the study to them in their local language. The study was approved by the review board of the institution.

Detailed history focusing on the presentation of diabetes mellitus (osmotic symptoms, ketoacidosis, or others), family history of diabetes, occupation, socioeconomic status, drug intake, menstrual history, and history of any systemic illness was recorded.

Direct sunlight exposure was assessed by average daily duration of exposure and percentage of body surface area exposed (20). Nutritional status of the patients and controls was assessed by a trained dietician based on the average composition of their daily diet in terms of energy, carbohydrate, protein, fat, and calcium content using a semi-quantitative food-frequency questionnaire $(21,22)$, and published data on nutrient composition of Indian food (23).

Examination of the subjects included recording of height, weight, body mass index (BMI), waist and hip circumference, and measurement of waist-to-hip ratio. BMI was calculated by the formula: body weight in $\mathrm{kg} /$ height in $\mathrm{m}^{2}$.

After overnight fasting, a venous blood sample was drawn for analysis of glucose, lipids, creatinine, calcium, phosphorus, and alkaline phosphatase. These biochemical measurements were determined by an automatic colorimetric method. HbAlc was measured with high performance liquid chromatography (HPLC) standardized for the DCCT assay (reference range, 4-6\%). The blood sample for estimation of $25(\mathrm{OH}) \mathrm{D}$ was allowed to clot at room temperature $\left(15-25^{\circ} \mathrm{C}\right)$ and centrifuged for 15 minutes to obtain hemolysis-free serum. Serum was then collected into separate plastic tubes and stored at $-20^{\circ} \mathrm{C}$. After rapid extraction from serum with acetonitrile; $25(\mathrm{OH}) \mathrm{D}$ was estimated by radioimmunoassay (RIA) procedure (catalogue no. 68100, Dia Sorin, Stillwater, Minnesota USA). The intra- and inter assay coefficients of variation ranged 
between $11.7-12.5 \%$ and $9.4-11 \%$, respectively. Samples were collected throughout the study duration with equal representations in winter and summer. The criteria used to define vitamin D status were: sufficiency (25OHD levels, $30-100 \mathrm{ng} / \mathrm{mL}$ ), insufficiency (25OHD, 20 to $30 \mathrm{ng} / \mathrm{mL}$ ), and deficiency (25OHD, <20 ng/mL) (1).

\section{Statistics}

Statistical analysis was performed using SPSS for Windows (version 11). Results were expressed as means \pm SD. A simple factorial analysis was used to find the correlation of between vitamin D status and the other clinical and biochemical parameters, after adjusting for age. An independent samples $t$ test was used to compare mean $\pm S D$ values between cases and controls; $p$-value less than 0.05 was considered as significant.

\section{RESULTS}

Seventy two patients of youth-onset diabetes mellitus were studied with a mean $\pm S D$ age of $16.72 \pm 0.68$ years. There were 33 males $(45.8 \%)$ and 39 females (54.2\%). Fifty eight $(86.4 \%)$ patients had type $2 \mathrm{DM}$ (26 were males and 32 were female), 13 (18.1\%) had type $1 \mathrm{DM}$ (6 males and 7 females) and one patient was classified as having FCPP. As seen in Table 1 , both cases and controls were comparable in age and BMI.

Overall plasma $25(\mathrm{OH}) \mathrm{D}$ levels were significantly lower in the patients (mean \pm SD of $7.88 \pm 1.20 \mathrm{ng} / \mathrm{mL}$ ) than in the control subjects (mean \pm SD of $16.64 \pm 7.83 \mathrm{ng} / \mathrm{mL}$; $\mathrm{p}=0.000)$. A high percentage of cases $(94.4 \%)$ as well as controls (58.5\%), had vitamin D deficiency. Mild and moderate VDD was seen more in controls than in cases, but severe VDD was seen more in patients with diabetes (60\%) compared with $8.3 \%$ in the controls (Table 1). Overall plasma levels of vitamin D did not reveal any correlation with sex, BMI, serum calcium, alkaline phosphate, and HbA1C

Table 1. Clinical and parameters of vitamin D status in people with diabetes and healthy controls

\begin{tabular}{lccc}
\hline Parameter & Cases $(\mathbf{n}=\mathbf{7 2})$ & Controls $(\mathbf{n}=\mathbf{4 1})$ & $\mathbf{p}$-value \\
\hline Age (years) & $16.72 \pm 0.68$ & $16.98 \pm 0.44$ & 0.79 \\
BMI $\left(\mathrm{kg} / \mathrm{m}^{2}\right)$ & $17.13 \pm 0.21$ & $17.47 \pm 3.49$ & 0.518 \\
Vitamin D $(\mathrm{ng} / \mathrm{mL})$ & $7.88 \pm 1.20$ & $16.64 \pm 7.83$ & 0.000 \\
VD sufficiency (\%) & $3 \pm 4.4$ & $3 \pm 7.3$ & 0.01 \\
VD insufficiency (\%) & $3 \pm 4.4$ & $14 \pm 34.1$ & - \\
VD deficiency (\%) & $91.1 \%$ & 58.5 & - \\
\hline
\end{tabular}

Data expressed as mean \pm SD unless indicated. BMI: body mass index; VD: vitamin D.
(Table 2). Mean \pm SD plasma $25(\mathrm{OH}) \mathrm{D}$ levels were marginally lower in the group with T1DM $(11.36 \pm 4.74 \mathrm{ng} / \mathrm{mL})$ compared with T2DM $(7.34 \pm 1.19 \mathrm{ng} / \mathrm{mL})$; but the difference was not statistically significant $(\mathrm{p}=0.260)$. Although T2DM was a larger group $(\mathrm{n}=58)$ compared with T1DM $(\mathrm{n}=13)$, an uniformly high percentage of patients $(92.3 \%$ in T1DM and $98.3 \%$ in T2DM) had vitamin D deficiency (Table 3).

Table 2. Correlation between vitamin D levels and various anthropometric and metabolic parameters

\begin{tabular}{ll}
\hline Vitamin D vs. & p-value \\
\hline Age & $0.009^{\$}$ \\
Gender & $0.390^{\$}$ \\
BMl & $0.810^{\$}$ \\
HDA1C & $0.061^{\$}$ \\
PGF & $0.859^{\$}$ \\
Calcium & $0.145^{\$}$ \\
ALP & $0.208^{\$}$ \\
\hline
\end{tabular}

HBA1C: hemoglobinA1C; BMI: body mass index; FPG: fasting plasma glucose; ALP: alkaline phosphatase; \$: age adjusted.

Table 3. Clinical and biochemical parameters and vitamin D status in T1DM vs. T2DM*

\begin{tabular}{lccc}
\hline Parameter & T1DM $(\mathbf{n = 1 3})$ & T2DM $(\mathbf{n}=\mathbf{5 8})$ & p-value \\
\hline Age & $15.15 \pm 1.89$ & $16.93 \pm 0.71$ & 0.312 \\
Sex (M/F) & $6 / 7$ & $26 / 32$ & - \\
BMl (kg/m²) & $16.81 \pm 0.55$ & $17.23 \pm 0.28$ & 0.532 \\
FPG (mg/dL) & $363.92 \pm 51.62$ & $318.25 \pm 21.30$ & 0.370 \\
HbA1C (\%) & $9.96 \pm 0.72$ & $11.19 \pm 0.41$ & 0.198 \\
Vitamin D (ng/mL) & $11.36 \pm 4.74$ & $7.34 \pm 1.19$ & 0.260 \\
Calcium (mg/dL) & $9.43 \pm 0.42$ & $9.07 \pm 0.15$ & 0.419 \\
Phosphorus (mg/dL) & $4.04 \pm 0.17$ & $3.91 \pm 0.10$ & 0.657 \\
ALP (U/L) & $533.66 \pm 2.21$ & $485.17 \pm 45.63$ & 0.662 \\
VDD (\%) & 88.3 & 97.5 & 0.246 \\
\hline
\end{tabular}

Data expressed as mean \pm SD. HBA1C: hemoglobin A1C; BMl: body mass index; PGF: fasting plasma glucose; ALP: alkaline phosphatase; VDD: vitamin D deficiency. ${ }^{*}$ One patient had FCPP.

\section{DISCUSSION}

Vitamin D deficiency is now regarded as pandemic in all age groups in humans $(4,24)$. High prevalence of VDD has been seen in normal healthy children at different ages. The main aim of the present study was to assess vitamin $\mathrm{D}$ status in new onset diabetes in the younger age group $(<25$ years), and in age- and gender-matched controls without diabetes. 
Using a serum vitamin D cutoff value of less than 20 $\mathrm{ng} / \mathrm{mL}$, high prevalence of VDD was seen in both groups of people with or without diabetes. VDD was seen in 58.5\% of healthy controls in the age group of $<25$ years, and $39 \%$ of them had 25(OH)D in the range of $5-10 \mathrm{ng} / \mathrm{mL}$, indicating moderate VDD. In a similar population of similar age, VDD was seen in $55 \%$ of normal subjects (5). The high percentage of VDD in the present study was attributed to decreased vitamin $\mathrm{D}$ intake, dark complexion, and winter months. A recent study has revealed VDD in as high as $85 \%$ of normal children in the age group $<16$ years, using a cutoff value of $<30 \mathrm{ng} / \mathrm{mL}$ (6). The high percentage of VDD in that study was explained by decreased sunshine exposure, limited outdoor activities, and decreased awareness about fortification with vitamin D. Similarly, vitamin D concentration of $<9 \mathrm{ng} / \mathrm{mL}$ was found in $35.7 \%$ of normal children in the age group of 10-18 years (24). Our study revealed a greater percentage of normal people (58.5\%) having VDD. Although sunshine exposure is good in India, it is limited to only few months, and fortification of food with vitamin $\mathrm{D}$ is not routine in the country.

Our main focus was to estimate vitamin D status in newly diagnosed youth-onset diabetes. We found that VDD was found in $94.4 \%$ of people with diabetes, compared with $58.5 \%$ of age- and sex- matched healthy controls. VDD was more prevalent in girls (65\%) compared with boys $(52.4 \%)$ in the healthy controls, and this gender difference was not seen in the diabetes group.

Some recent studies have focused on the prevalence of VDD in people with T1DM. Prevalence varied from as high as $90.60 \%$ with a vitamin D cutoff value of $<30 \mathrm{ng} /$ $\mathrm{mL}$ in Qatar (6), to as low as $15 \%$ with a vitamin D cutoff value of $<20 \mathrm{ng} / \mathrm{mL}$ at Joslin's diabetes center (9), and intermediate prevalence of $54 \%$ with a vitamin D cutoff value of $<32 \mathrm{ng} / \mathrm{mL}$ in DIASS study (8). In one north Indian study, 58\% children with T1DM aged between 6 and 12 year were vitamin D-deficient as compared with only $32 \%$ in the control group (25). In our study $25(\mathrm{OH}) \mathrm{D}$ was significantly lower (mean \pm SD of $7.88 \pm 1.20 \mathrm{ng} / \mathrm{mL}$ ) in patients, compared with $16.64 \pm 7.83 \mathrm{ng} / \mathrm{mL}$ in the controls. Many recently published studies have found significantly lower levels of $25(\mathrm{OH}) \mathrm{D}$ in patients with diabetes compared with controls $(6,8,10,26)$.

The universal findings of low vitamin $\mathrm{D}$ in people with T1DM have implications in its pathogenesis. As early as 1980 , it was found that VDD in rabbits inhibited pancreatic insulin secretion (27). There is evidence that vitamin $\mathrm{D}$ regulates beta-cell function by either influencing insulin secretion, inhibiting beta-cell apoptosis, or by increasing beta-cell replication (28). In the context of T1DM, vitamin $\mathrm{D}$ has a significant role in altering self-immunity leading to diabetes (29). Assessing the data on the incidence of T1DM in children $<14$ years in 51 regions across the globe, incidence rate of T1DM approached zero in regions with high UVB irradiance (30). The association of adequate vitamin $\mathrm{D}$ and incidence of T1DM is also reflected by seasonal variations in the incidence of T1DM. It has been observed that children born in the spring are associated with increasing likelihood of T1DM (31). The association of hypovitaminosis D and T1DM is further strengthened by laboratory studies. An association between vitamin $\mathrm{D}$ receptor (VDR) polymorphism and T1DM was reported in Indian, German, and Taiwan populations (32-34). Also, polymorphism in CYP 27B1 gene has been shown to decrease the local expression of 1-alpha-hydroxylase, and subsequent decreased conversion of $25(\mathrm{OH}) \mathrm{D}$ to $1: 25(\mathrm{OH}) 2 \mathrm{D}$, increasing the predisposition to T1DM.

In the present study, high prevalence of hypovitaminosis $\mathrm{D}$ in people with diabetes could point to an association between the two disorders in our community. Type $2 \mathrm{DM}$ is a disorder resulting from defects in insulin sensitivity and secretion. The disorder is more common in obese individuals with sedentary lifestyle and higher levels of inflammatory cytokines (35). Many studies have suggested that vitamin D could have a role in improving beta-cell function and increasing insulin sensitivity. The National Health and Nutrition Examination Survey (NHANES) showed an inverse correlation between $25(\mathrm{OH}) \mathrm{D}$ and the incidence of $\mathrm{T} 2 \mathrm{DM} / \mathrm{insulin}$ resistance. (36). A similar inverse relationship between $25(\mathrm{OH}) \mathrm{D}$ and glycemic status was found in other studies $(37,38)$. In the present study, serum $25(\mathrm{OH}) \mathrm{D}$ was also significantly lower in patients with T2DM when compared with healthy controls. The direct clinical evidence of the association between hypovitaminosis $\mathrm{D}$ and diabetes has come from interventional studies; these studies are more robust for T1DM. The use of cod liver oil during the first year of life was associated with lower risk of T1DM (39). A reduction as high as $29 \%$ in the risk of T1DM was seen in infants supplemented with vitamin $\mathrm{D}$ compared with controls in the meta-analysis of four studies (40). In the EURODIAB study, a reduction as high as $30 \%$ in the risk of T1DM was seen with vitamin D supplementation early in life (13).

Clinical intervention studies with T2DM are less consistent. In Nurses' Health Study which followed a large cohort of women over 20 years, a combined intake of $>800$ $\mathrm{U}$ of vitamin $\mathrm{D}$ was associated with a decrease of $33 \%$ in the risk of T2DM compared with the intake of $<600 \mathrm{mgs}$ 
of calcium and $400 \mathrm{U}$ of vitamin D (41). These results have not been reproduced yet. In the Women's Health Initiative Study, calcium in low doses and 400 IU of vitamin D per day were not shown to be protective. Similarly, in one study, no improvement in glucose tolerance has been seen with vitamin $\mathrm{D}$ supplementation in vitamin $\mathrm{D}$ sufficient individuals (42). Genetic background, baseline vitamin D, and the vitamin $\mathrm{D}$ dose given may be important determinants in such discrepancy. The present study also revealed that vitamin D levels were significantly low in patients with T2DM compared with controls. It could be postulated that either hypovitaminosis D has increased insulin resistance or impaired beta-cell function, or both, but that was not the aim of the study.

There are several limitations of our study: we separated patients in type 1 and type 2 diabetes on the basis of hard evidence of diabetic ketoacidosis in favor of T1DM. Although maturity-onset diabetes of young (MODY) is common among Indians (43), we could not classify any patient in MODY, as all of them required insulin from the beginning, and continue to be on insulin. We did not measure their beta-cell reserve, nor did we estimate their islet cell antibodies, but we believe that absence of these investigations did not affect the results, as we had the broader aim of -finding vitamin D status in youth-onset diabetes.

In summary, the aim of the current prospective study was to find vitamin D status in seventy two newly detected youth-onset diabetes, both type 1 and T2 DM (age < 25 years) and 41 age- and gender-matched controls. Both cases and controls were vitamin $\mathrm{D}$ deficient. The mean serum $25(\mathrm{OH}) \mathrm{D}$ was significantly low in people with diabetes compared with controls. Levels of $25(\mathrm{OH}) \mathrm{D}$ did not correlate with age, sex, BMI, nutritional calcium intake, plasma glucose, and $\mathrm{HbA1C}$. Whether vitamin D status in patients with diabetes has a role in the pathogenesis of diabetes mellitus in younger patients needs to be elucidated in future studies.

Disclosure: no potential conflict of interest relevant to this article was reported.

\section{REFERENCES}

1. Holick MF. High prevalence of vitamin D inadequacy and implications for health. Myo Clin Proc. 2006;81(3):353-73.

2. Holick MF. Vitamin D deficiency. N Engl J Med. 2007;357(3):266-81.

3. Ramakrishnan S, Bhansali A, Bhadada SK, Sharma R, Walia R, Ravikiran $M$, et al. Vitamin D status and its seasonal variability in healthy young adults in an Asian Indian urban population. Endocrine Pract. 2011;17(2):185-91.

4. Zargar AH, Ahmad S, Masoodi SR, Wani Al, Bashir MI, Laway BA, et al. Vitamin D status in apparently healthy adults in Kashmir valley of Indian subcontinent. Postgrad Med J. 2007;83(985):713-6.
5. Weng FL, Shults J, Leonard MB, Stalling VA, Zemel BS. Risk factors for low 25-hydroxyvitamin $D$ concentrations in otherwise healthy children and adolescents. Am J Clin Nutr. 2007;86(1):150-8.

6. Bener A, Alsaied A, Al-Ali M, Al-Kubaisi A, Basha B, Abraham A, et al. High prevalence of vitamin $D$ deficiency in type 1 diabetes mellitus and healthy children. Acta Diabetol. 2009;46(3):183-9.

7. Mathieu C, Gysemans C, Giulietti A, Bouillon R. Vitamin D and diabetes. Diabetologia. 2005;48(7):1247-57.

8. Littorin B, Blom P, Schölin A, Arnqvist HJ, Blohmé G, Bolinder J, et al. Lower levels of plasma 25-hydroxyvitamin $D$ among young adults at diagnosis of autoimmune type 1 diabetes compared with control subjects: results from the nationwide Diabetes Incidence Study in Sweden (DISS). Diabetologia. 2006;49(12):2847-52.

9. Svoren BM, Volkening LK, Wood JR, Laffel LM. Significant vitamin $D$ deficiency in youth with type 1 diabetes mellitus. J Pediatr. 2009;154(1):132-4.

10. Janner $M$, Ballinari $P$, Mullis $P E$, Flück $C E$. High prevalence of vitamin $D$ deficiency in children and adolescents with type 1 diabetes. Swiss Med Wkly. 2010;140:w13091.

11. Rewers M, Norris J, Dabelea D. Epidemiology of type 1 diabetes mellitus. Adv Exp Med Biol. 2004;552:219-46.

12. Casteels K, Waer M, Bouillon R, Depovere J, Valckx D, Laureys J, et al. 1,25-dihydroxyvitamin D3 restores sensitivity to cyclophosphamide-induced apoptosis in non-obese diabetic (NOD) mice and protects against diabetes. Clin Exp Immunol. 1998;112(2):181-7.

13. Vitamin $D$ supplement in early childhood and risk for Type I (insulin-dependent) diabetes mellitus. The EURODIAB Sub study 2 Study Group. Diabetologia. 1999;42(1):51-4.

14. Pittas AG, Dawson-Hughes B, LiT, Van Dam RM, Willett WC, Manson JE, et al. Vitamin $\mathrm{D}$ and calcium intake in relation to type 2 diabetes in women. Diabetes Care. 2006;29(3):650-6.

15. Liu S, Song Y, Ford ES, Manson JE, Buring JE, Ridker PM. Dietary calcium, vitamin $D$, and the prevalence of metabolic syndrome in middle-aged and older U.S. women. Diabetes Care. 2005;28(12):2926-32.

16. Pittas AG, Harris SS, Stark PC, Dawson-Hughes B. The effects of calcium and vitamin $D$ supplementation on blood glucose and markers of inflammation in nondiabetic adults. Diabetes Care. 2007;30(4):980-6.

17. Zargar AH, Bhat MH, Laway BA, Masoodi SR. Clinical and aetiological profile of early onset diabetes mellitus: data from a tertiary care centre in the Indian subcontinent. J Postgrad Med. 2001;47(1):27-9.

18. Zargar AH, Wani AA, Laway BA, Masoodi SR, Wani Al, Bashir MI, et al. Prevalence of diabetes mellitus and other abnormalities of glucose tolerance in young adults aged $20-40$ years in North India (Kashmir Valley). Diabetes Res Clin Pract. 2008;82(2):276-81.

19. Zargar AH, Khan AK, Masoodi SR, Laway BA, Wani Al, Bashir MI, et al. Prevalence of type 2 diabetes mellitus and impaired glucose tolerance in the Kashmir Valley of the Indian subcontinent. Diabetes Res Clin Pract. 2000;47(2):135-46.

20. Mcgrouther DA. Skin burns. In: Mann CV, Russel RCG, Williams NS, eds. Bailey and Love's short practice of surgery, London; Chapman and Hall, 1995:124-48.

21. Laway BA, Goswami R, Singh N, Gupta N, Seith A. Pattern of bone mineral density in sporadic idiopathic hypoparathyroidism. Clin Endocrinol (Oxf). 2006;64(4):405-9.

22. Willett WC, Sampson L, Stampfer MJ, Rosner B, Bain C, Witschi $\mathrm{J}$, et al. Reproducibility and validity of a food frequency questionnaire. Am J Epidemiol. 1985;122(1):51-65.

23. Gopalan C, Rama Sastri BV, Balasubramanian SC, eds. Nutritive value of Indian foods: food composition tables. National Institute of Nutrition, Indian Council of Medical Research, Hyderabad, India; 1996. p. 45-95. 
24. Marwaha RK, Tandon N, Reddy DR, Aggarwal R, Singh R, Sawhney $\mathrm{RC}$, et al. Vitamin $\mathrm{D}$ and bone mineral density status of healthy schoolchildren in northern India. Am J Clin Nutr. 2005;82(2):477-82.

25. Borkar VV, Devidayal, Verma S, Bhalla AK. Low levels of vitamin $D$ in North Indian children with newly diagnosed type 1 diabetes. Pediatr Diabetes. 2010;11(5):345-50.

26. Pozzilli $P$, Manfrini $S$, Crinò A, Picardi A, Leomanni $C$, Cherubini $V$, et al. IMDIAB group. Low levels of 25-hydroxyvitamin D3 and 1,25-dihydroxyvitamin D3 in patients with newly diagnosed type 1 diabetes. Horm Metab Res. 2005;37(11):680-3.

27. Nyomba BL, Auwerx J, Bormans V, Peeters TL, Pelemans W, Reynaert $J$, et al. Pancreatic secretion in man with subclinical vitamin D deficiency. Diabetologia. 1986;29(1):34-8.

28. Takiishi T, Gysemans $C$, Bouillon R, Mathieu C. Vitamin D and diabetes. Endocrinol Metab Clin North Am. 2010;39(2):419-46.

29. Zella JB, DeLuca HF. Vitamin D and autoimmune diabetes. J Cell Biochem. 2003;88(2):216-22.

30. Mohr SB, Garland CF, Gorham ED, Garland FC. The association between ultraviolet $B$ irradiance, vitamin $D$ status and incidence rates of type 1 diabetes in 51 regions worldwide. Diabetologia. 2008;51(8):1391-8.

31. Kahn HS, Morgan TM, Case LD, Dabelea D, Mayer-Davis EJ, Lawrence JM, et al. SEARCH for Diabetes in Youth Study Group. Association of type 1 diabetes with month of birth among U.S. youth: The SEARCH for Diabetes in Youth Study. Diabetes Care. 2009;32(11):2010-5.

32. Pociot F, McDermott MF. Genetics of type 1 diabetes mellitus. Genes Immun. 2002;3(5):235-49.

33. Pani MA, Knapp M, Donner H, Braun J, Baur MP, Usadel KH, et al. Vitamin $\mathrm{D}$ receptor allele combinations influence genetic susceptibility to type 1 diabetes in Germans. Diabetes. 2000;49(3):504-7.
34. Chang TJ, Lei HH, Yeh JI, Chiu KC, Lee KC, Chen MC, et al. Vitamin $\mathrm{D}$ receptor gene polymorphisms influence susceptibility to type 1 diabetes mellitus in the Taiwanese population. Clin Endocrinol (Oxf). 2000;52(5):575-80.

35. Zimmet P, Alberti KG, Shaw J. Global and societal implications of the diabetes epidemic. Nature. 2001;414(6865):782-7.

36. Scragg R, Sowers M, Bell C. Serum 25-hydroxyvitamin D, diabetes, and ethnicity in the Third National Health and Nutrition Examination Survey. Third National Health and Nutrition Examination Survey. Diabetes Care. 2004;27(12):2813-8.

37. Chiu KC, Chu A, Go VL, Saad MF. Hypovitaminosis D is associated with insulin resistance and beta cell dysfunction. Am J Clin Nutr. 2004;79(5):820-5.

38. Forouhi NG, Luan J, Hennings S, Wareham NJ. Incidence of Type 2 diabetes in England and its association with baseline impaired fasting glucose: the Ely study 1990-2000. Diabet Med. 2007;24(2):200-7.

39. Stene LC, Ulriksen J, Magnus P, Joner G. Use of cod liver oil during pregnancy associated with lower risk ofType I diabetes in the offspring. Diabetologia. 2000;43(9):1093-8.

40. Zipitis CS, Akobeng AK. Vitamin D supplementation in early childhood and risk of type 1 diabetes: a systematic review and meta-analysis. Arch Dis Child. 2008;93(6):512-7.

41. Pittas AG, Dawson-Hughes B, LiT, Van Dam RM, Willett WC, Manson $\mathrm{JE}$, et al. Vitamin $\mathrm{D}$ and calcium intake in relation to type 2 diabetes in women. Diabetes Care. 2006;29(3):650-6.

42. Cigolini M, lagulli MP, Miconi V, Galiotto M, Lombardi S, Targher G. Serum 25-hydroxyvitamin D3 concentrations and prevalence of cardiovascular disease among type 2 diabetic patients. Diabetes Care. 2006;29(3):722-4.

43. Mohan V, Ramachandran A, Snehalatha C, Mohan R, Bharani G, Viswanathan M. High prevalence of maturity-onset diabetes of the young (MODY) among Indians. Diabetes Care. 1985;8(4):371-4. 